\title{
Clinical haematology of the great bustard (Otis tarda)
}

\author{
A. JIMENEZ, R. BARRERA, J. SANCHEZ, RAFAELA CUENCA, J. RODRIGUEZ, \\ S. ANDRES \& MARÍA CINTA MAÑE \\ Departamento de Medicina y Sanidad Animal, Facultad de Veterinaria, Universidad de \\ Extremadura, Carretera de Trujillo s/n. 10071 Cáceres, Spain
}

\begin{abstract}
SUMMARY
The haematological parameters of healthy great bustards (Otis tarda L.) have been determined. The values obtained were red cell count $\left(3.0 \times 10^{12} \pm 0.2 \times 10^{12} / 1\right)$, white cell count $\left(33.0 \times 10^{9} \pm 2.6 \times 10^{9} / 1\right)$, haematocrit value $(0.51 \pm 0.011 / 1)$, haemoglobin $(13.0 \pm 0.3$ $\mathrm{g} / \mathrm{dl})$, mean corpuscular volume $(178.7 \pm 12.5 \mathrm{fl})$, mean cell haemoglobin concentration $(25.0 \pm 0.6 \mathrm{~g} / \mathrm{dl})$, mean corpuscular haemoglobin $(42.5 \pm 3.2 \mathrm{pg})$, differential white cell count: heterophils $\left(22.5 \times 10^{9} \pm 0.7 \times 10^{9} / 1\right)$, lymphocytes $\left(6.0 \times 10^{9} \pm 0.7 \times 10^{9} / 1\right)$, eosinophils $\left(2.7 \times 10^{9} \pm 0.3 \times 10^{9} / 1\right)$ and monocytes $\left(1.8 \times 10^{9} \pm 0.2 \times 10^{9} / 1\right)$.
\end{abstract}

\section{INTRODUCTION}

The great bustard is an endangered species in Europe. Therefore, all the efforts aimed at the protection of this species must be supported.

In the past few years, we have seen an increase in the numbers of these birds taken to the Clinic of Internal Medicine due to pathological problems. For this reason we have studied the haemophysiological parameters, with the purpose of establishing reference values.

\section{MATERIALS AND METHODS}

Thirty-six clinically healthy birds were chosen at random without chemical immobilization, from the Las Seguras. The birds were between 1 and 11 years of age. The animals have been kept on a 124-acre farm. We cannot accept, therefore, that they were in absolute captivity. The birds were fed on insects and other casual seasonal food.

Heparinized blood ( $5 \mathrm{ml}$ samples) obtained by venipuncture from the ulnaris vein, was analysed as follows: erythrocyte and leucocyte counts (Natt \& Herrick, 1952), using Neubauer's haemocytometer; haemoglobin, using a spectrophotometrical modification to the acid haematin technique; mean corpuscular haemoglobin $(\mathrm{MCH})$; mean corpuscular volume (MCV); mean corpuscular haemoglobin concentration (MCHC); haematocrit (after centrifugation at $9072 \mathrm{~g}$ ); differential leucocyte count, from thin blood film was stained with Diff-Quick's fast colouring technique (Dade Grifols-Laboratories).

Received 8 January 1991; Accepted 22 April 1991. 
Table 1. Mean values ( $\pm S E M$ ) (grand, male and female) corresponding to the different parameters of the red series

\begin{tabular}{lcrc}
\hline & Grand & Males & \multicolumn{1}{c}{ Females } \\
\hline RBC $\left(\times 10^{12} / 1\right)$ & $3.0 \pm 0.2$ & $3.7 \pm 0.4$ & $2.8 \pm 0.2$ \\
Hb $(\mathrm{g} / \mathrm{dl})$ & $13.0 \pm 0.3$ & $13.9 \pm 0.6$ & $12.6 \pm 0.5$ \\
Haematocrit $(1 / 1)$ & $0.51 \pm 0.01$ & $0.5 \pm 2.3$ & $0.5 \pm 1.3$ \\
MCV $(\mathrm{f})$ & $178.7 \pm 12.5$ & $123.3 \pm 6.6$ & $201.7 \pm 22.1$ \\
MCHC $(\mathrm{g} / \mathrm{dl})$ & $25.0 \pm 0.6$ & $27.2 \pm 0.8$ & $24.0 \pm 0.1$ \\
MCH $(\mathrm{pg})$ & $42.5 \pm 3.2$ & $31.9 \pm 1.5$ & $47.0 \pm 6.1$ \\
\hline
\end{tabular}

Table 2. Mean values ( $\pm S E M$ ) (grand, male and female) corresponding to the different parameters of the white series

\begin{tabular}{lrrr}
\hline & Grand & \multicolumn{1}{c}{ Males } & \multicolumn{1}{c}{ Females } \\
\hline WBC $\left(\times 10^{9} / 1\right)$ & $33.0 \pm 2.6$ & $32.3 \pm 4.0$ & $30.5 \pm 3.4$ \\
Heterophils $\left(\times 10^{9} / 1\right)$ & $22.5 \pm 0.7$ & $20.8 \pm 1.2$ & $21.0 \pm 0.8$ \\
Lymphocytes $\left(\times 10^{9} / 1\right)$ & $6.0 \pm 0.7$ & $6.7 \pm 1.5$ & $5.8 \pm 0.8$ \\
Eosinophils $\left(\times 10^{9} / 1\right)$ & $2.7 \pm 0.3$ & $2.6 \pm 0.8$ & $2.4 \pm 0.3$ \\
Monocytes $\left(\times 10^{9} / 1\right)$ & $1.8 \pm 0.2$ & $2.2 \pm 0.1$ & $1.3 \pm 0.2$ \\
\hline
\end{tabular}

\section{RESULTS AND DISCUSSION}

The data obtained were subjected to a simple analysis of variance carried out to determine the effect of sex. The results are given in Tables 1 and 2 .

No protozoa or microfilarine were seen in blood smears. The mean number of erythrocytes differed between males and females $(P<0.005)$. Similar differences have been described by Hunsaker et al. (1964) for the goose (Anser anser), Sturkie (1967) for the chicken (Gallus domesticus) and Nirmalan \& Robinson (1971) for the quail (Coturnix coturnix). The mean value of $3.0 \times 10^{12} \mathrm{RBC} / 1$ is the same as the one obtained by Balasch et al. (1974) for different avian species.

The haemoglobin values for the species were $13.0 \mathrm{~g} / \mathrm{dl}$, similar to those obtained by other authors (Balasch et al., 1973, 1974, 1976) for birds such as the brown pelican (Pelicanus occidentalis occidentalis), imperial eagle (Aquila heliaca) or Andean condor (Vultur gryphus). However, the observed mean haemoglobin value was larger than that found by Alonso et al. (1990) in free-living young great bustards, $11.7 \mathrm{~g} / \mathrm{dl}$. This may reflect the differences in age. Adult birds usually have higher values as demonstrated by Tanaka \& Rosenberg (1954) and Deaton et al. (1969) in the chicken (Gallus domesticus), by Hunsaker et al. (1964) in the goose (Anser anser) and by Atwal et al. (1964) in the quail (Coturnix coturnix).

The haematocrit value for great bustards, $0.511 / 1$, is greater than that reported by Alonso et al. (1990) of $41 \%$ in free-living young great bustards. The mean MCV value obtained in our experiment, at $178.7 \mathrm{fl}$, is somewhat larger than that reported by Alonso et $a l .(1990)$ in free-living young great bustards $(166.6 \mathrm{fl})$, and very much higher than that quoted for the domestic fowl (Gallus domesticus) by other authors (Abou-Ashour \& 


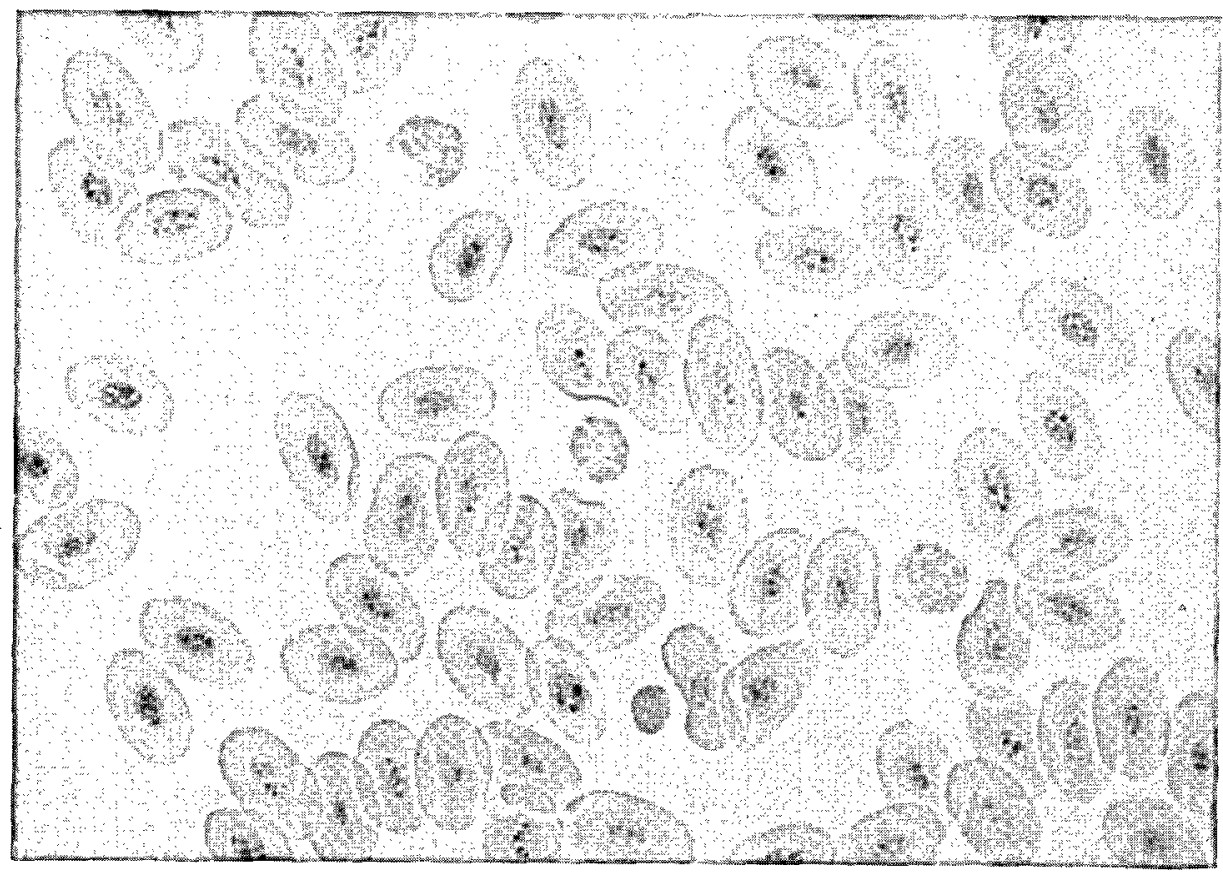

Figure 1. Three lymphocytes in a bustard blood smear.

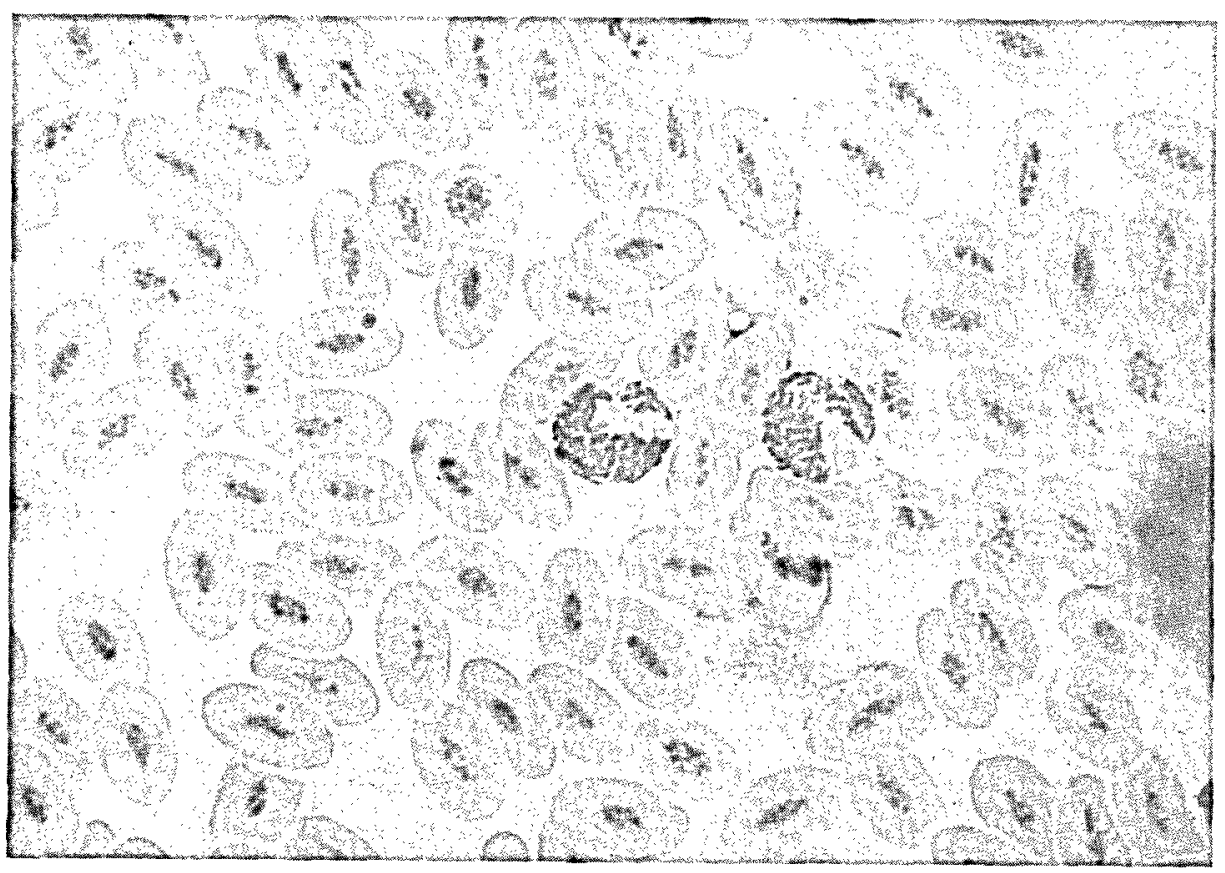

Figure 2. Two heterophils in a bustard blood smear. 


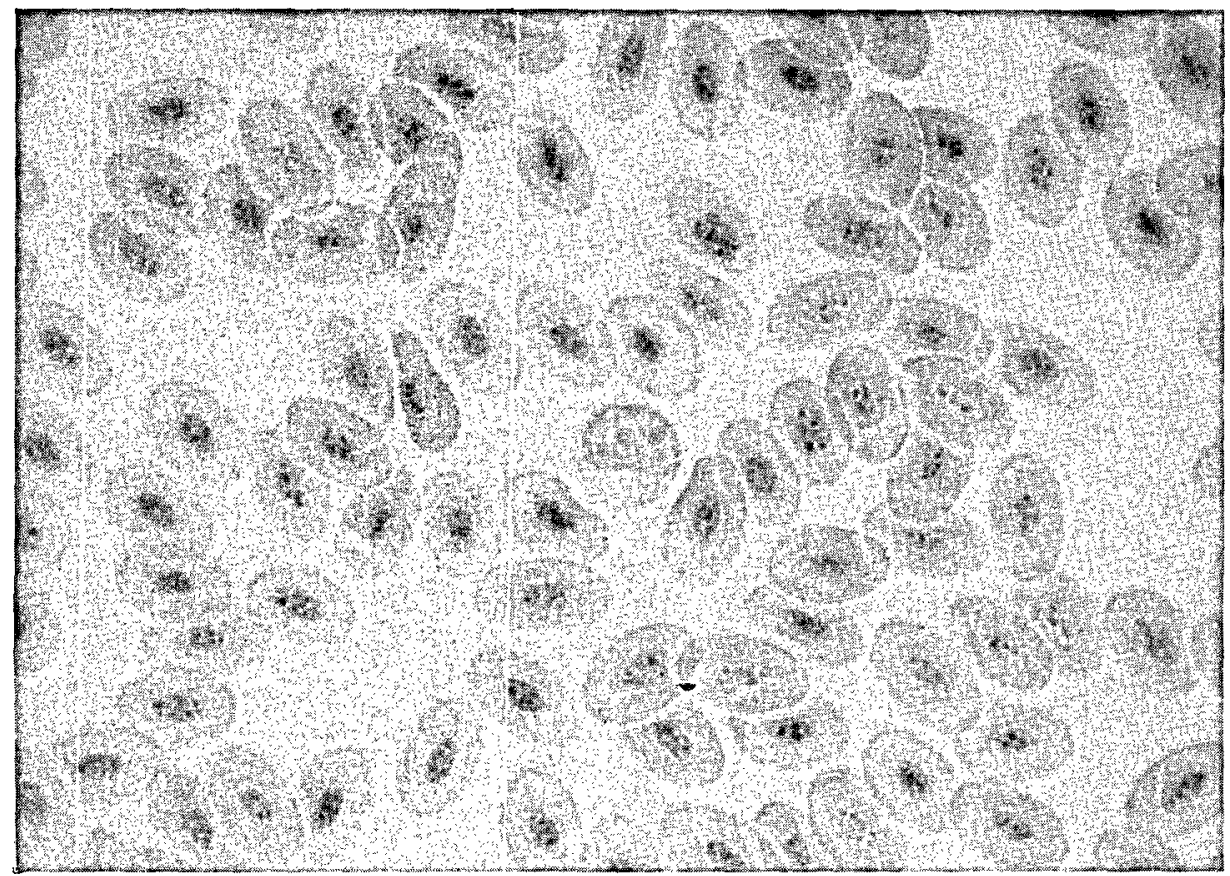

Figure 3. A monocyte from a bustard.

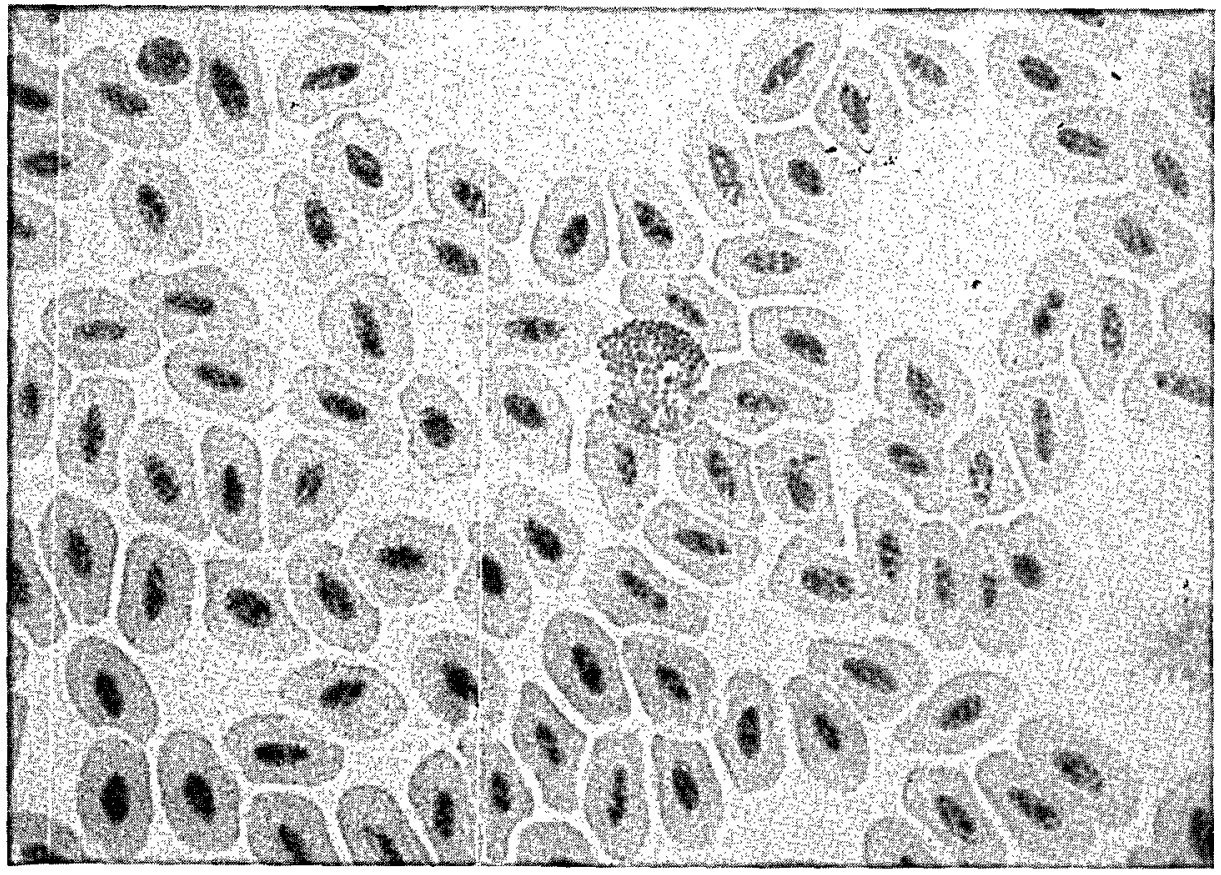

Figure 4. An eosinophil in a bustard blood film. 
Edwards, 1972). In contrast the mean $M C M H$ value of $25.0 \mathrm{~g} / \mathrm{dl}$, was less than that observed by Alonso et al. (1990) of $28.5 \mathrm{~g} / 100 \mathrm{ml}$ and considerably smaller than the mean value found by Jones \& Johansen (1972) in several avian species such as domestic chicks (Gallus domesticus), wild ducks (Anas platyrhynchos) and wild turkeys (Meleagris gallopavo). This difference might be due, in part, to different centrifugational forms being employed in different studies.

The leucocytes values observed (Table 2) are similar to those obtained by Lucas \& Jamroz (1961) for domestic chicks (Gallus domesticus) and by Venkataratnam \& Clarkson (1962) for the peacock (Pavo cristatus). Nevertheless, the value of WBC count is much larger than that found by Alonso et al. (1990) in free-living young great bustards $\left(11,000 \mathrm{WBC} / \mathrm{mm}^{3}\right)$. This difference may be due to the fact that Alonso et al. (1990) examined young birds in their experiment, while all birds in this paper were adults.

The differential count of leucocytes in most birds, usually shows a higher percentage of lymphocytes (Figure 1). In great bustards, heterophils (Figure 2) are the predominant leucocytes, as in the case with the wild turkey (Meleagris gallopavo), the ring-necked pheasant (Phasianus colchicus), and the ostrich (Struthio camelus) (Fredrickson et al.; 1956; Schalm, 1981), with granules and colourless cytoplasm (Figure 2). The numbers of monocytes (Figure 3), and eosinophils (Figure 4), are comparable with those found in other birds (Sturkie, 1967).

\section{REFERENCES}

Abou-Ashour, A.M. \& Edwards, H.M. (1972). Haematological changes in laying hens receiving Sterculia foetida oil supplements. Poultry Science, 51, 300-305.

Alonso, J.A., Alonso, J.C., Muñoz-Pulido, R., Naveso, L.A., Abelenda, M., Huecas, V. \& Puerta, M.L. (1990). Haematology and blood chemistry of free-living young great bustards. Comparative Biochemistry $\&$ Physiology, 97A, 611-614.

Atwal, O.S., MCFARLAND, LZ. \& Wilson, W.O. (1964). Haematology of Coturnix from birth to maturity. Poultry Science, 43, 1392-1401.

Balasch, J., Palacios, L., Musquera, S., Palomeque, J., Jimḱnez, M. \& Alemany, M. (1973). Comparative haematologycal values of several galliformes. Poultry Science, 52, 1531-1534.

Balasch, J., Palomeque, J., Palacios, L., Musquera, S. \& Jlménez, M. (1974). Haematological values of some great flying and aquatic-diving birds. Comparative Biochemistry \& Physiology, 49A, 137-145.

Balasch, J., Musquera, S., Palacios, L., Jiménez, M. \& Palomeque, J. (1976). Comparative haematology of some falconiforms. Condor, 78, 258-273.

DEATON, J.W., REECE, F.N. \& TARNER, W.J. (1969). Haematocrit, haemoglobin and plasma-protein levels of broilers reared under constant temperatures. Poultry Science, 48, 1993-1996.

Fredrickson, T.N., ChuTe, H.L. \& O'MeARA, D.C. (1956). Preliminary investigations on the haematology of broiler flocks. 28th Annual Meeting of the Northeastern Conference of Laboratory Workers in Pullorum Disease Control, pp. 67-74 (Newark, Delaware, University of Delaware).

Hunsaker, W.G., Hunt, J.R. \& AitKen, J.R. (1964). Physiology of the growing and adult goose. I. Physical characteristics of blood. British Poultry Science, 5, 249-256.

Jones, D.R. \& Johansen, K. (1972). The blood vascular system of birds, in: D. S. Farner \& J. R. KIng (Eds) Avici: Biology II, pp. 157-285 (London, Academic Press).

LuCAS, A.M. \& JAMROZ, C. (1961). Atlas of avian haematology, Agriculture Monograph 25 (Washington, U.S. Dept. of Agriculture).

NATT, M.P. \& HerRick, C.A. (1952). A new blood diluent for counting the erythrocytes and leucocytes of the chicken. Poultry Science, 31, 735-738.

Nirmalan, G.P. \& Robinson, G.A. (1971). Haematology of the Japanese quail (Coturnix coturnix japonica). British Poultry Science, 12, 475-481.

SChalm, O.W. (1981). Hematologia veterinaria, pp. 505-568 (Buenos Aires, Hemisferio Sur S.A.).

STURKIE, P.D. (1967). Fisiologia Aviar, pp. 5-29 (Zaragoza, Ed. Acribia).

TANAKA, T. \& Rosenberg, M.M. (1954). Relationship between haemoglobin levels in chickens and certain characters of economic importance. Poultry Science, 33, 821-827.

Venkataratnam, A. \& Clarkson, M.J. (1962). The blood cells of the turkey. Research in Veterinary Science, 3, $455-459$. 


\section{RESUME}

\section{Hematologie clinique de L'outarde (otis tarda L.)}

Dans ce travail on analysé plusieurs des paramètres hématiques des outardes (Otis tarda L.).

Les valeurs obtenues sont les suivantes dénombrement total d'hématies $\left(3.0 \times 10^{12} \pm 0.2 \times 10^{12} / 1\right)$, denombrement total de leucocytes $\left(33.0 \times 010^{9} \pm 2.6 \times 10^{9} / 1\right)$, valeur hématocrite $(0.51 \pm 0.011 / 1)$, concentration d'hémoglobine $(13.0 \pm 0.3 \mathrm{~g} / \mathrm{dl})$, volumen corpusculaire moyen $(178.7 \pm 12.5 \mathrm{fl})$, concentration corpusculaire moyenne d'hémoglobine $(25.0 \pm 0.6 \mathrm{~g} / \mathrm{dl})$, hémoglobine corpusculaire moyenne $(42.5 \pm 3.2 \mathrm{pg})$ et formule leucocytaire héterophyles $\left(22.5 \times 10^{9} \pm 0.7 \times 10^{9} / 1\right)$, lymphocites $\left(6.0 \times 10^{9} \pm 0.7 \times 10^{9} / 1\right)$, eosinophyles $\left(2.7 \times 10^{9} \pm 0.3 \times 10^{9} / 1\right)$ et monocytes $\left(1.8 \times 10^{9} \pm 0.2 \times\right.$ $\left.10^{9} / 1\right)$.

\section{ZUSAMMENFASSUNG}

\section{Klinische Hämatologie der Großtrappe (otis tarda L.)}

Bei dieser Arbeit wurden verschiedene Blutparameter der Trappen (Otis tarda L.) analysiert. Es wurden folgende Werte errechnet.

Gesamtählung der roten Blutkörperchen $\left(3.0 \times 10^{12} \pm 0.2 \times 10^{12} / 1\right)$, Zählung der weißen Blutkörperchen $\left(33.0 \times 10^{9} \pm 2.6 \times 10^{9} / 1\right)$, hämatokrischer Wert $(0.51 \pm 0.01 \mathrm{1} / 1)$, Hamoglobinkonzentration $(13.0 \pm 0.3 \mathrm{~g} / \mathrm{dl})$, mittleres Körperchengröße $(178.7 \pm 12.5 \mathrm{fl})$, mittlere Körperchenmenge des Hämoglobin $(25.0 \pm 0.6 \mathrm{~g} / \mathrm{dl})$, mittleres Körperchenhämog!obin $(42.5 \pm 3.2 \mathrm{pg})$ sowie prozentuale Komposition der weißen Blutkörperchen: Heterophile $\left(22.5 \times 10^{9} \pm 0.7 \times 10^{9} / 1\right)$, Lymphozyte $\left(6.0 \times 10^{9} \pm 0.7 \times 10^{9} / 1\right)$, Eosinophile $\left(2.7 \times 10^{9} \pm 0.3 \times 10^{9} / 1\right)$, Monozyte $\left(1.8 \times 10^{9} \pm 0.2 \times 10^{9} / 1\right)$.

\section{RESUMEN}

\section{Hematologia clinica de la avutarda (otis tarda L.)}

En este trabajo se han analizado varios parametros hematicos de las avutardas (Otis tarda L.).

Los valores obtenidos son los siguientes: recuento total de hematies $\left(3.0 \times 10^{12} \pm 0.2 \times 10^{12} / 1\right)$, recuento de glóbulos blancos $\left(33.0 \times 10^{9} \pm 2.6 \times 10^{9} / 1\right)$, valor hematocrito $(0.51 \pm 0.011 / 1)$, concentración de hemoglobina $(13.0 \pm 0.3 \mathrm{~g} / \mathrm{dl})$, volumen corpuscular medio $(178.7 \pm 12.5 \mathrm{f})$, concentración corpuscular media de hemoglobina $(25.0 \pm 0.6 \mathrm{~g} / \mathrm{dl})$, hemoglobina corpuscular media $(42.5 \pm 3.2 \mathrm{pg})$ y fórmula leucocitaria: heterófilos $\left(22.5 \times 10^{9} \pm 0.7 \times 10^{9} / 1\right)$, infocitos $\left(6.0 \times 10^{9} \pm 0.7 \times 10^{9} / 1\right)$, eosinófilos $\left(2.7 \times 10^{9} \pm 0.3 \times 10^{9} / 1\right)$ y monocitos $\left(1.8 \times 10^{9} \pm 0.2 \times 10^{9} / 1\right)$. 